\title{
Study of the block/grout interface in concrete and clay block masonry structures
}

\section{Estudo da interface bloco/graute em alvenaria de blocos cerâmicos e de concreto}
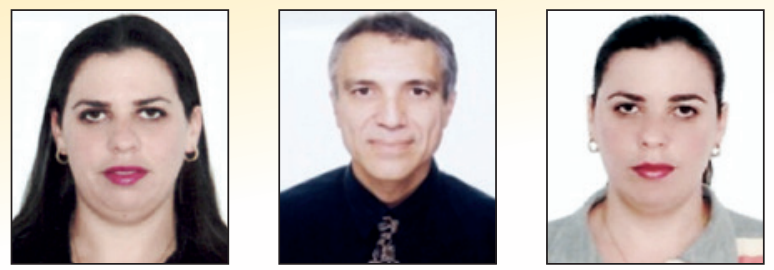

\section{O. S. IZQUIERDO a \\ orietasi@uft.edu.br}

M. R. S. CORRÊA b

marcio.correa@usp.br

I. I. SOTO

indaritasi@gmail.com

\begin{abstract}
This work aims to study the behavior of the block/grout interface for concrete and clay block masonry. This was achieved by push-out and pullout experimental tests including reinforcement bar in the latter one. The experimental result showed that there is a good bond between the concrete blocks internal faces and the grout, enough to prevent infill-slippage, and that the whole tensile strength of the usual reinforcement bars is achieved provided they are properly anchored. Nevertheless, for clay blocks there is a low bond between the clay blocks internal faces and the grout, allowing the infill-slippage before the reinforcement bars reach their yield stress.
\end{abstract}

Keywords: block/grout interface, bond stress, compressive strength, bond strength, grouting.

\section{Resumo}

Este trabalho objetiva o estudo do comportamento da interface bloco/graute em alvearia de blocos cerämicos e de concreto. Tal objetivo foi alcançado com ensaios laboratoriais de empurramento e arrancamento, sendo estes útimos com a inclusão de barras de armadura. Os resultados experimentais mostraram que existe uma boa aderência entre as faces internas dos blocos de concreto e o graute, suficiente para evitar o seu deslizamento, e que as barras de aço atingem a sua resistência última de tração, desde que devidamente ancoradas no graute. No entanto, no caso dos blocos cerâmicos, ocorre uma baixa aderência entre o graute e as faces internas do bloco, podendo levar a um deslizamento do graute antes que as barras de aço atinjam a sua resistência ao escoamento.

Palavras-chave: interface bloco/graute, aderência, resistência à compressão, resistência de aderência, grauteamento. 


\section{Introduction}

Two types of bond should be considered when evaluating the performance of reinforced masonry: the bond between reinforcing steel and grout, and the bond between the grout and the internal faces of the unit. The bond which can be developed between the reinforcement and the surrounding grout is a complex phenomenon which is dominated by the interlocking action of the reinforcing bar ribs in the grout mass. However, the bond between the grout and the surrounding masonry unit is primarily limited by the adhesion formed at the interface [1].

The slippage mechanism between the contact surfaces is similar to the phenomenon of the bond between rebar and grout. In both cases, the bond strengths are influenced by the microscopic and macroscopic irregularities of the contact surfaces. Grout fills the micro or macro cavities, forming imbrication points that mechanically constrain the slippage. The bond loss is related to the absence or destruction of these imbrication points [2].

There are not many research reports on the study of block/grout interface of structural masonry.

Pereira de Oliveira [3] researched the relationship between the block/grout bond strength and the compressive masonry strength of concrete block. For that, the author studied several types of grouts varying the water/cement ratio and the specific area of the aggregates. This study showed that the grout bond strength is improved with the decrease of the water/cement ratio and that this strength increases when increasing the specific area of the aggregates until a maximum point and then decreases. The compressive masonry strength is raised by an improvement of the bond capacity between the concrete block and grout.

Biggs [4] tested mortar as a substitute for grout in reinforced masonry by testing the pull-out strength of reinforcement embedded in mortar. The author compared the performance of two-concretehalf-block prisms (406.4 $\mathrm{mm}$ high) containing reinforcing bars inserted in grout or mortar infills. Four types of mortar infill and two types of grout were studied. Although the results show that the grout samples present a higher failure load than the mortar infill samples, the author concluded that Portland cement-lime based mortar has the potential to be an acceptable alternative for grout in reinforced masonry. Some of the results of Biggs[4] will be compared to those obtained in the present work.

Soric and Tulin [1] studied the bond between the reinforcement rebar and the grout, and the bond between the grout and the masonry units. The bond strength between the grout infill and the concrete unit was determined by push-out tests. The specimens consisted of a single half block, fully grouted, to which a compressive load was applied at the top surface of the grout through a bearing plate while the block was supported only around its masonry shell. The bond stress at failure was determined by dividing the maximum applied load by the area of the interface surface of the masonry unit. The average bond stress obtained from push-out tests was of approximately $1.52 \mathrm{MPa}$. The authors suggest that more testing should be performed for the definitive characterization.

Soric and Tulin [5] studied the reinforced masonry bond applying experimental pull-out tests in specimens of concrete and clay blocks with the presence of reinforcement bars. This bond stress depends on the ribbed bar pattern, the applied load, the embedment length, and the grout characteristics. Two types of block materials (concrete and clay) and two rebar diameters $(12.5 \mathrm{~mm}$ and $16 \mathrm{~mm}$ ) were tested, also varying the embedment length. They concluded that the behavior of the clay masonry units specimen and reinforced with $12.5 \mathrm{~mm}$ bars was similar to those made with concrete masonry units. The specimen reinforced with $16 \mathrm{~mm}$ rebar and constructed of clay masonry units reached a maximum stress equivalent to $25 \%$ of the yield stress of the steel bar, while the concrete unit specimen reached $50 \%$ of the steel bar yield stress.

Ahmed and Feldman [6] rated the contact and noncontact lap splices in concrete block masonry construction. Contact and noncontact lap splices, where the lapped bars were located in adjacent cells, were tested in both double pullout and wall splice concrete block specimens. Visual observations of the incurred damage were also reviewed to identify the resulting failure modes. A statistically significant difference was found between the results of the double pullout and wall splice specimens with the same reinforcing arrangements, and for the different reinforcing arrangements in the same specimen type. Specimens with contact lap splices failed due to bar pullout. Evidence of bond loss at the grout-block interface was observed for specimens with noncontact lap splices and appeared to have influenced the resulting failure mode and lap splice resistance.

Camli and Binici [7] studied the bond strength of carbon fiber reinforced polymers bonded to concrete and masonry. The study presents the results of 57 double shear push-out tests conducted to determine the strength of carbon fiber reinforced polymers (CFRPs) bonded to concrete prisms and hollow clay tiles that are finished with and without plaster. In the experimental program, different types of anchorage methods were tested in a double shear push-out test setup. It was found that strength of CFRPs bonded to hollow clay tiles are significantly lower than CFRPs bonded to concrete. Lower bond strengths were observed for hollow clay tile specimens due to weak tile texture and discontinuities on the tile surface.

Aiello and Sciolti [8] made a bond analysis of masonry structures strengthened with CFRP sheets. The study has been carried out on naples tuff and leccese stone specimens reinforced with FRP sheets, glued onto the surface of the stones. It was observed that the bond stress-slip law proposed by reference [9], referring to FRP reinforced concrete structures, could be appropriate for predicting the interface behavior of FRP strengthened masonry structures. The author concluded that the maximum bond strength, Tmax, is mainly affected by the properties of the substrate, being higher for specimens made by leccese stone, by about $50 \%$, with respect to the values registered for the naples tuff. In this case, in fact, the flexural strength of the substrate is the main determining parameter, considering that the debonding started at the loaded end, within the substrate layer.

\subsection{Justification}

Despite the scarce and inconclusive experimental results, the international standardization gives little attention to the subject, with exception of the Brazilian Standard of Concrete Block Structural Masonry [10] and the Clay Block Structural Masonry [11]. They suggest that the maximum tensile stress of the reinforcement embedded in the grout cannot be higher than $50 \%$ of its yield stress 
$\left(0.5 \sigma_{y}\right)$. This is an indirect way of limiting the shear stress at the interface grout/unit. This request is relevant for high rise buildings (buildings with 20 floors in structural masonry are not unusual in Brazil. Therefore, the present study is justified mainly because the need to establish such limits.

Thus, the main objective of this paper is to study the behavior of the block/grout interface in concrete and clay blocks, by means of experimental "push-out" and "pull-out" tests.

\section{Materials and experimental program}

The experimental program studied the masonry behavior using push-out specimens to determine the bond strength between the grout and the concrete unit, and pull-out specimens to study the behavior of the interface of the grout/block/reinforcement set. Two types of block materials (concrete and clay), two types of grout (large and small compressive resistance) and two rebar diameters $(12.5 \mathrm{~mm}$ and $16 \mathrm{~mm}$ ) were considered. These laboratory tests were preceded by a set of materials characterization tests, and additional tests to verify the roughness of the unit and infill surfaces.

\subsection{Push-out test}

The push-out specimens consisted of a single concrete block with one of its cavities completely grouted. The salient grout from the surface of the block at a distance of $30 \mathrm{~mm}$ was loaded in compression through a bearing plate at the top surface, while the block was supported only around the perimeter of the unit shells at the bottom surface. The bond stress at failure was calculated by dividing the maximum applied load by the area of the interface surface between the grout and the masonry unit, when slippage was evident. Figure 1 shows the nominal dimensions of the pushout specimens.

The structural concrete blocks have conic holes, that is, the webs have varying thickness along the height. The results shown in this work correspond to the situation in which the greater thicknesses are facing up with the load applied down. Therefore, it favors safety. Two types of grout were studied. Grout G14 with a low compressive strength (14 MPa) and high water/cement ratio (0.95) and grout $\mathrm{G} 30$ with high compressive strength $(30 \mathrm{MPa})$ and low water/cement ratio $(0.65)$. Note that the grout denominations are not standard, used here to point out the main difference between the two types.

Two series were used for testing the push-out specimens, depending on the grout type.

\subsection{Pull-out}

The pull-out specimens of concrete blocks were built with five concrete blocks in stack bond formation, with one of their cavities completely grouted and with a reinforcement rebar embedded in the grout. The first 4 blocks were grouted, leaving the last empty block for support. The pull-out clay block specimens were built with four concrete blocks in stack bond. The 4 blocks were grouted. The reinforcement rebar was subjected to a tensile load in order to study the grout/block/reinforcement set. Figure 2 shows the nominal dimensions of the pull-out specimens.

Those specimens had different types of grout (grout G14 and grout G30) and rebar diameters (12.5 mm and $16 \mathrm{~mm}$ ). Four series were built with 6 specimens for each series:

- Series G14S12: Grout G14 and rebar diameters $12.5 \mathrm{~mm}$;

- Series G30S12: Grout G30 and rebar diameters $12.5 \mathrm{~mm}$;

- Series G14S16: Grout G14 and rebar diameters 16 mm;

- Series G30S16: Grout G30 and rebar diameters 16 mm.

Complementary tests were carried out to characterize the masonry: compressive strength testing of cylindrical mortar specimens, cylindrical grout specimens and units. They were rectified to obtain regular and smooth surfaces. The rebars were subjected to tensile strength tests. The internal surfaces of units and grout were also tested for roughness, since that property determines the expected differences in bond related to imbrication points.

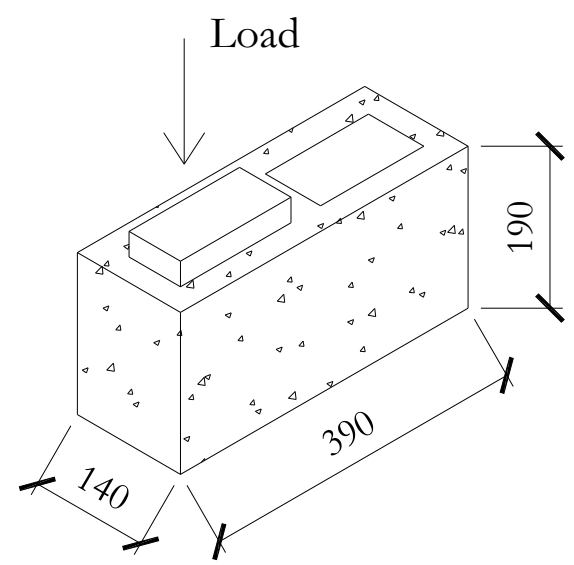

A

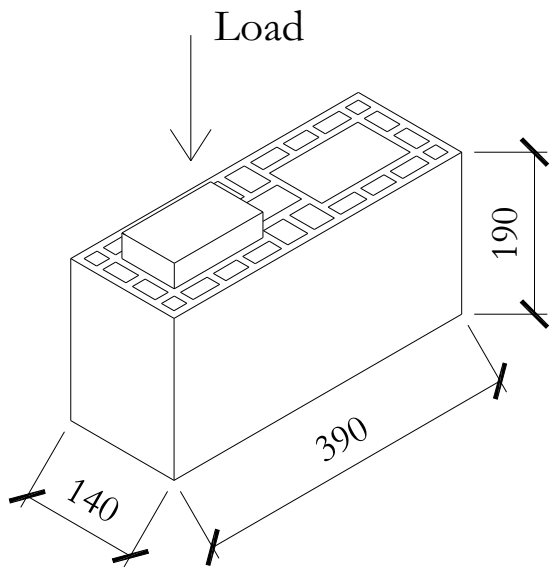

B

Figure 1

Nominal dimensions of the push-out specimens of: concrete block (a) and clay block (b) (in mm) 


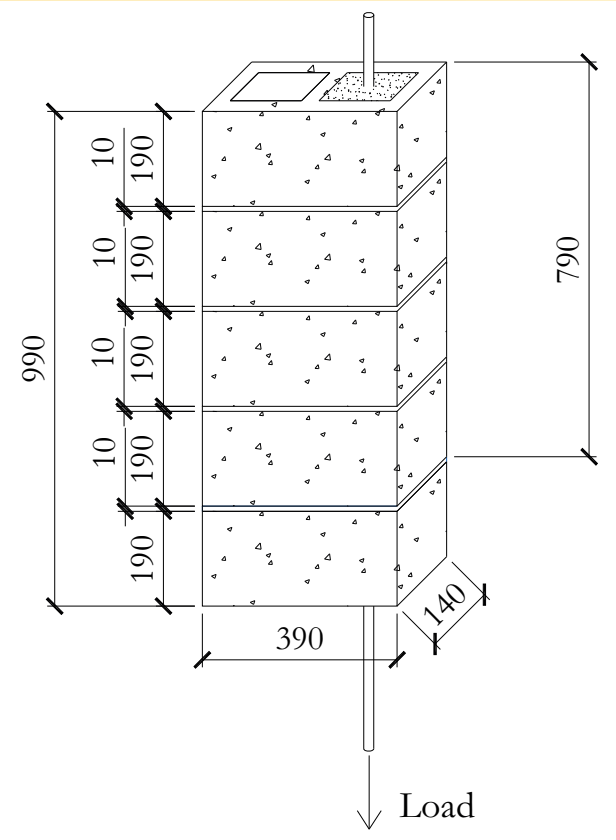

A

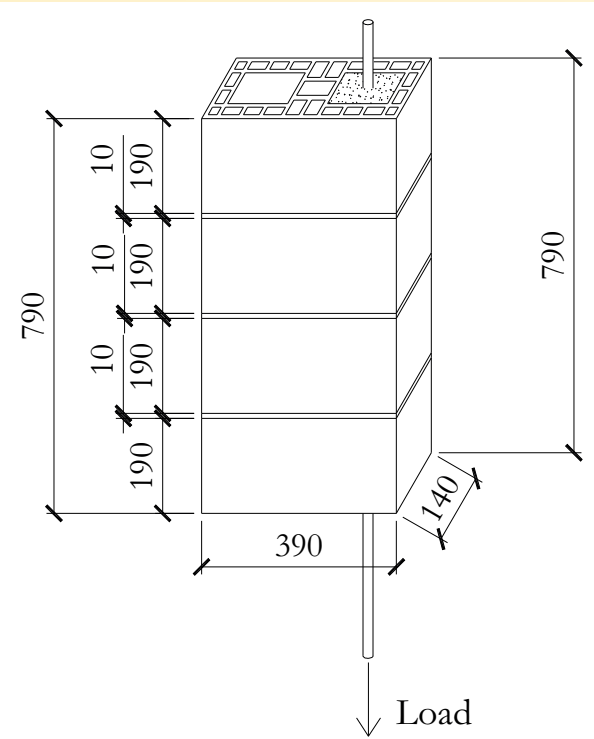

B

\section{Figure 2}

Nominal dimensions of the pull-out specimens: concrete blocks (a) and clay blocks (b) (in mm)

\subsection{Specimen types}

The designation describes the specimen configuration. For example, Co10G14S12 means: Co10 (or Co26 or Cl10) = concrete (or clay) masonry units of 10 or $26 \mathrm{MPa}$ compressive strength; G14 (or $\mathrm{G} 30$ ) = grout of $14 \mathrm{MPa}$ compressive strength (or grout of $30 \mathrm{MPa}$ ); $\mathrm{S} 12($ or S16) $=12.5 \mathrm{~mm}$ (or $16.0 \mathrm{~mm}$ ) steel bar diameter.

\subsection{Materials and their properties}

The cement and lime used in this study were CP II Z and CH III, respectively. According to the Brazilian Standard [12], the cement and lime present specific density of $3.07 \mathrm{~g} / \mathrm{cm}^{3}$ and $2.45 \mathrm{~g} / \mathrm{cm}^{3}$, respectively. The fine and coarse aggregates were sand and basalt crushed rock of zero graduation. These materials are readily available in the market and were used under the same conditions in which they are usually employed in construction sites.

The sand used in this study meets the requirements of the Brazilian Standard [13] and can be classified as fine sand in zone 2, as shown in Figure 3.

The results of the characterization of the fine and coarse aggregates are presented in Table 1.

\section{Results and discussions}

The experimental results are presented below. They are divided in two groups: concrete and clay blocks.
Statistical tests were applied to evaluate the differences of the experimental results at a $5 \%$ significance level, for a better understanding of the results.

The statistical test $\mathrm{F}$ was applied for the analysis of the homogeneity of variances and next the T-test or "Student's t test", in view of the previously performed $F$ test, to compare the

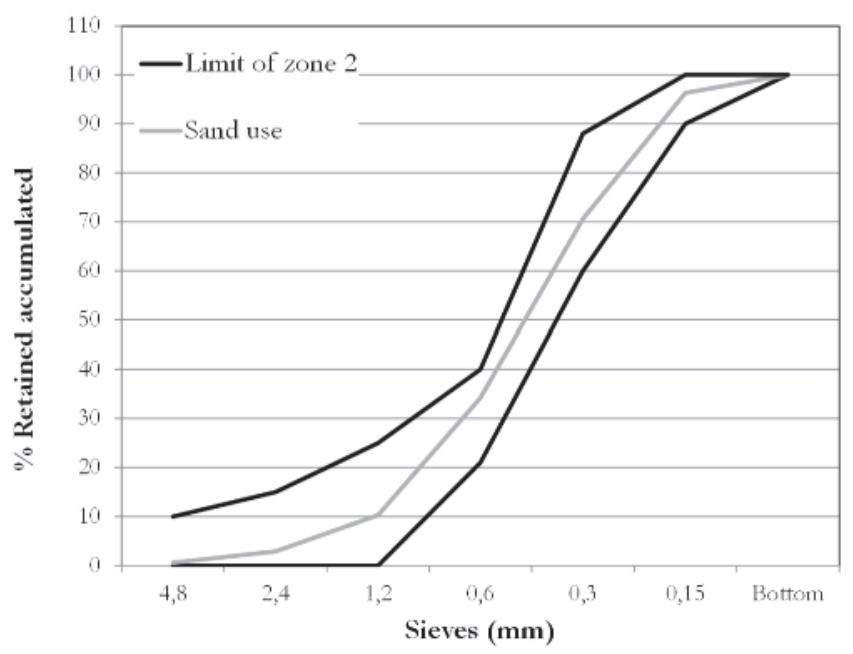

Figure 3

Comparison between the sand used in this study and that recommended by the (13)

\section{Table 1}

Physical characteristics of sand and gravel

\begin{tabular}{|c|c|c|c|c|}
\hline Materials & $\begin{array}{c}\text { Specific weight } \\
\left(\mathbf{g} / \mathbf{c m}^{\mathbf{3}}\right)\end{array}$ & $\begin{array}{c}\text { Bulk density } \\
\left(\mathbf{k g} / \mathbf{m}^{3}\right)\end{array}$ & Fineness modulus & $\begin{array}{c}\text { Maximum diameter } \\
(\mathbf{m m})\end{array}$ \\
\hline Sand & 2.62 & 2.59 & 2.15 & 2.40 \\
\hline Gravel & 2.86 & 2.70 & 5.87 & 9.5 \\
\hline
\end{tabular}


Table 2

Results of the compressive strength of mortar

\begin{tabular}{|c|c|c|c|}
\cline { 2 - 4 } \multicolumn{1}{c|}{} & $\begin{array}{c}\text { Clay } \\
\text { blocks }\end{array}$ & $\begin{array}{c}\text { Concrete } \\
\text { blocks } \\
\text { Class 1 }\end{array}$ & $\begin{array}{c}\text { Concrete } \\
\text { blocks } \\
\text { Class 2 }\end{array}$ \\
\hline $\begin{array}{c}\text { Mean strength } \\
\text { (MPa) }\end{array}$ & 4.96 & 4.45 & 5.85 \\
\hline COV (\%) & 7.11 & 12.74 & 11.96 \\
\hline
\end{tabular}

samples' means. The null hypothesis was the equality of means or variances of the two data sets. Note that the Student's test is appropriate for a small sample size. Winter [14] applied successfully this test to extremely small sample sizes.

\subsection{Compressive strength}

\subsubsection{Mortar}

Table 2 shows the mean compressive strength results of the mortar used in the experimental program. Six cylindrical mortar sample specimens were tested at 28 days. The volume proportion of mortar was 1:0.5:4.5 (cement: lime: sand) and the water/cement ratio of 1.60. The use of two classes of concrete units is explained in section 3.3 .

This volume ratio was selected in this work to keep the mortar less resistant and more deformable than the units, to accommodate small deformations. The two mortars did not show significant differences.

\subsubsection{Grout}

Six cylindrical grout specimens were tested at 28 days for each grout type. The mass proportion of grout G14 was 1:3.06:2.94 (cement: sand: gravel) with a water/cement ratio of 0.95 and grout G30 was prepared using a mass proportion 1:1.90:2 (cement: sand: gravel) and a water/cement ratio of 0.65 . Both types of grout are representative of the most used in Brazil, and are sufficient to the aims of this study.

Table 3 shows the mean of the compressive strength results for grout G14 and G30 used for filling the clay blocks and the two classes of concrete blocks specimens.

As already mentioned, grout G14 was designed to be weaker than grout G30. Statistical analysis showed significant differences between the results for the different types of grout, for both concrete and clay blocks. The values obtained for the same type of grout did not show significant differences. Therefore, there was a rigorous control in the production of both types of grouts for each type of blocks.

\subsubsection{Blocks}

Six concrete blocks (for two different classes) and six clay blocks were tested under compression. Table 4 presents the results of the compressive strength of the blocks, related to the gross area. The use of concrete units of two different compressive strengths is explained in section 3.3.

The results in Table 4 show that the mean compressive strength of the clay and the weakest concrete blocks was similar. Statistically, these values are not different at a $5 \%$ significance level. The differences of the two classes of concrete blocks are statically significant.

Table 3

Results of the compressive strength of grout $G 14$ and $G 30$ for concrete blocks

\begin{tabular}{|c|c|c|c|c|c|c|c|c|c|}
\hline \multirow[b]{2}{*}{ Grout } & \multicolumn{3}{|c|}{ Clay blocks } & \multicolumn{3}{|c|}{ Concrete blocks - Class 1} & \multicolumn{3}{|c|}{ Concrete blocks - Class 2} \\
\hline & $\begin{array}{c}\text { Mean } \\
\text { load } \\
(\mathrm{kN})\end{array}$ & $\begin{array}{l}\text { Mean } \\
\text { compres. } \\
\text { strength } \\
\text { (MPa) }\end{array}$ & $\begin{array}{l}\text { Slump } \\
(\mathrm{mm})\end{array}$ & $\begin{array}{c}\text { Mean } \\
\text { load } \\
(\mathrm{kN})\end{array}$ & $\begin{array}{l}\text { Mean } \\
\text { compres. } \\
\text { strength } \\
(\mathrm{MPa})\end{array}$ & $\begin{array}{l}\text { Slump } \\
(\mathrm{mm})\end{array}$ & $\begin{array}{c}\text { Mean } \\
\text { load } \\
(k N)\end{array}$ & $\begin{array}{l}\text { Mean } \\
\text { compres. } \\
\text { strength } \\
(\mathrm{MPa})\end{array}$ & $\begin{array}{c}\text { Slump } \\
(\mathrm{mm})\end{array}$ \\
\hline G14 & 111.35 & 14.18 & 216 & 112.60 & 14.34 & 224 & 119.05 & 15.16 & 235 \\
\hline COV (\%) & 2.97 & 2,96 & 0.93 & 5.26 & 5.26 & 0.51 & 2.40 & 2.77 & 1.13 \\
\hline G30) & 246.83 & 31.43 & 222 & 235.92 & 30.04 & 234 & 253.18 & 32.38 & 244 \\
\hline cov (\%) & 2.83 & 2.84 & 1.37 & 3.16 & 3.16 & 1.08 & 0.76 & 0.68 & 2.02 \\
\hline
\end{tabular}

\section{Table 4}

Results of the compressive strength of the blocks

\begin{tabular}{|c|c|c|c|c|c|c|}
\cline { 2 - 7 } & \multicolumn{2}{c|}{ Clay blocks } & \multicolumn{2}{c|}{ Concrete blocks - Class 1 } & \multicolumn{2}{c|}{ Concrete blocks - Class 2 } \\
\cline { 2 - 7 } & $\begin{array}{c}\text { Mean load } \\
(\mathrm{kN})\end{array}$ & $\begin{array}{c}\text { Mean } \\
\text { compres. } \\
\text { strength (MPa) }\end{array}$ & $\begin{array}{c}\text { Mean load } \\
(\mathrm{kN})\end{array}$ & $\begin{array}{c}\text { Mean } \\
\text { compres. } \\
\text { strength (MPa) }\end{array}$ & $\begin{array}{c}\text { Mean load } \\
(\mathrm{kN})\end{array}$ & $\begin{array}{c}\text { Mean } \\
\text { compres. } \\
\text { strength (MPa) }\end{array}$ \\
\cline { 2 - 7 } & 586.58 & 10.89 & 557.03 & 10.21 & 1403.38 & 26.02 \\
\hline $\operatorname{COV}(\%)$ & 13.70 & 13.94 & 5.03 & 4.78 & 0.06 & 0.06 \\
\hline
\end{tabular}


Table 5

Results of the tensile strength of reinforcements

\begin{tabular}{|c|c|c|c|c|c|}
\hline \multicolumn{5}{|c|}{ Tensile strength of reinforcements of clay blocks } \\
\hline \multirow{2}{*}{ Diameter rebar } & & $\begin{array}{c}\text { Mean ultimate } \\
\text { load (kN) }\end{array}$ & $\begin{array}{c}\text { Mean yield load } \\
(\mathbf{k N})\end{array}$ & $\begin{array}{c}\text { Mean ultimate } \\
\text { load (kN) }\end{array}$ & $\begin{array}{c}\text { Mean yield load } \\
(\mathbf{k N})\end{array}$ \\
\hline \multirow{2}{*}{$12.5 \mathrm{~mm}$} & - & 93.32 & 65.55 & 760.43 & 534.15 \\
\cline { 2 - 6 } & COV (\%) & 1.39 & 2.95 & 1.39 & 2.95 \\
\hline \multirow{2}{*}{$16 \mathrm{~mm}$} & - & 159.86 & 117.32 & 795.05 & 583.52 \\
\cline { 2 - 7 } & COV (\%) & 1.20 & 2.79 & 1.20 & 2.79 \\
\hline
\end{tabular}

\begin{tabular}{|c|c|c|c|c|c|}
\hline \multicolumn{7}{|c|}{ Tensile strength of reinforcements of concrete blocks - Class 1 (Col0) } \\
\hline \multirow{2}{*}{ Diameter rebar } & & $\begin{array}{c}\text { Mean ultimate } \\
\text { load (kN) }\end{array}$ & $\begin{array}{c}\text { Mean yield load } \\
(\mathrm{kN})\end{array}$ & $\begin{array}{c}\text { Mean ultimate } \\
\text { load (kN) }\end{array}$ & $\begin{array}{c}\text { Mean yield load } \\
(\mathrm{kN})\end{array}$ \\
\hline \multirow{2}{*}{$12.5 \mathrm{~mm}$} & - & 98.95 & 68.26 & 806.32 & 556.24 \\
\cline { 2 - 7 } & COV (\%) & 0.82 & 2.18 & 0.82 & 2.18 \\
\hline \multirow{2}{*}{$16 \mathrm{~mm}$} & - & 141.97 & 118.35 & 706.10 & 588.60 \\
\cline { 2 - 7 } & COV (\%) & 1.29 & 2.02 & 1.30 & 2.02 \\
\hline
\end{tabular}

\begin{tabular}{|c|c|c|c|c|c|}
\hline \multicolumn{2}{|c|}{ Tensile strength of reinforcements of concrete blocks - Class 2 (Co26) } \\
\hline \multirow{2}{*}{ Diameter rebar } & & $\begin{array}{c}\text { Mean ultimate } \\
\text { load (kN) }\end{array}$ & $\begin{array}{c}\text { Mean yield load } \\
(\mathrm{kN})\end{array}$ & $\begin{array}{c}\text { Mean ultimate } \\
\text { load (kN) }\end{array}$ & $\begin{array}{c}\text { Mean yield load } \\
(\mathrm{kN})\end{array}$ \\
\hline \multirow{2}{*}{$12.5 \mathrm{~mm}$} & - & 89.14 & 70.25 & 711.44 & 572.49 \\
\cline { 2 - 6 } & COV (\%) & 0.57 & 4.51 & 3.10 & 4.51 \\
\hline \multirow{2}{*}{$16 \mathrm{~mm}$} & - & 139.78 & 116.74 & 694.67 & 580.63 \\
\cline { 2 - 6 } & COV (\%) & 0.84 & 6.79 & 6.92 & 6.79 \\
\hline
\end{tabular}

\subsection{Tensile strength of reinforcements}

Three $12.5 \mathrm{~mm}$ and $16 \mathrm{~mm}$ steel rebar samples were submitted to direct tensile tests. Table 5 shows the results obtained for the reinforcement used in clay blocks and concrete blocks. The yield stress was calculated according to Brazilian Standards [15].

\subsection{Push-out tests}

\subsubsection{Bond strength of the push-out specimens}

The bond strength was determined dividing the maximum load applied by the area of the internal cavity surface of the unit. The area calculated for a clay block hole was $722 \mathrm{~cm}^{2}$ and for a concrete clay block hole it was $813 \mathrm{~cm}^{2}$. Table 6 displays the results for clay and concrete blocks. Note that in the case of concrete units,

\section{Table 6}

Results of the push-out tests

\begin{tabular}{|c|c|c|c|c|c|c|}
\cline { 2 - 7 } & \multicolumn{2}{|c|}{ Clay blocks } & \multicolumn{2}{c|}{$\begin{array}{c}\text { Concrete blocks (Co10) } \\
\text { Class 1 }\end{array}$} & \multicolumn{2}{c|}{$\begin{array}{c}\text { Concrete blocks (Co26) } \\
\text { Class 2 }\end{array}$} \\
\cline { 2 - 7 } & $\begin{array}{c}\text { Mean ultimate } \\
\text { load (kN) }\end{array}$ & $\begin{array}{c}\text { Bond strength } \\
\text { (MPa) }\end{array}$ & $\begin{array}{c}\text { Mean ultimate } \\
\text { load (kN) }\end{array}$ & $\begin{array}{c}\text { Lower limit of } \\
\text { bond strength } \\
\text { (MPa) }\end{array}$ & $\begin{array}{c}\text { Mean ultimate } \\
\text { load (kN) }\end{array}$ & $\begin{array}{c}\text { Lower limit of } \\
\text { bond strength } \\
\text { (MPa) }\end{array}$ \\
\hline G14 & 11.64 & 0.16 & 38.40 & 0.47 & 107.42 & 1.32 \\
\hline COV (\%) & 11.31 & 11.31 & 11.38 & 11.36 & 12.70 & 12.70 \\
\hline G30 & 14.02 & 0.19 & 53.65 & 0.66 & 146.56 & 1.80 \\
\hline COV (\%) & 8.87 & 8.87 & 9.47 & 9.47 & 5.33 & 5.33 \\
\hline
\end{tabular}



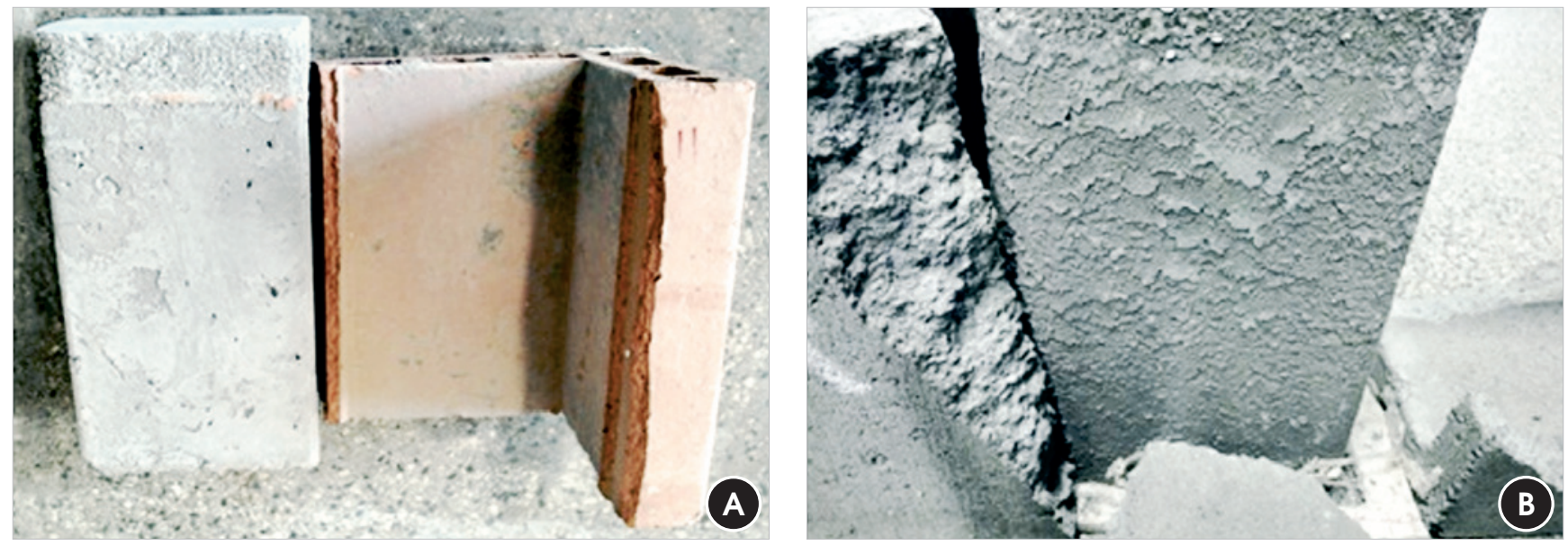

\section{Figure 4}

Types of surfaces created between the grout and clay blocks ( $a$ ) and concrete blocks (b)

the ratio "failure load/internal cavity area" is not the bond strength itself but only a lower limit of that property, since failure is typically caused by tension in the units, as described below. After obtaining this failure type, we decided to add higher tensile strength concrete units (Class 2 blocks have a mean tensile strength of 2.56 $\mathrm{MPa}$, while Class 1 blocks have $0.91 \mathrm{MPa}$ ). Even for the strongest concrete blocks, the failure type was the same (see section 3.3.2). Depending on the type of grout, the results obtained show that the bond strength in the grout/block interface was higher for grout G30, the one with higher compressive strength and lower water/ cement ratio. The interface for grout G14 presented low resistance. Statistically, these values show significant differences in all cases. Hence, the type of grout influenced the bond between the block webs and grout, and this influence was more noticeable in the concrete blocks.

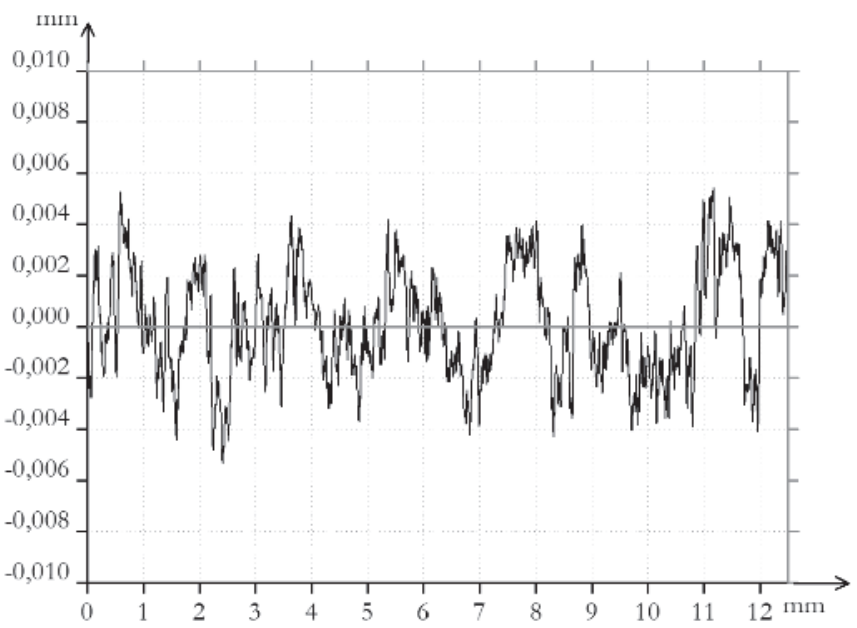

A
Pereira de Oliveira [3] concluded that the bond strength in the grout/ block interface is improved with the decrease of the water/cement ratio. This conclusion is consistent with the push-out results obtained in this research, despite the differing grout proportion.

Soric and Tulin [1] obtained average bond strength of 1.52 MPa for a grout with $19 \mathrm{MPa}$ compressive strength and a concrete block with $15.61 \mathrm{MPa}$. They described the same type of failure obtained in the present study (spalling of the masonry shell) and decided to present the obtained lower limit as the bond strength of the interface, consistent with what is done in the present paper. Note that the referred bond strength of $1.52 \mathrm{MPa}$ is somehow close to the obtained values for the strongest blocks.

According to the type of block material, the results in Table 6 show a higher bond strength in the concrete blocks than in the clay blocks. Statistical analysis showed significant differences between those

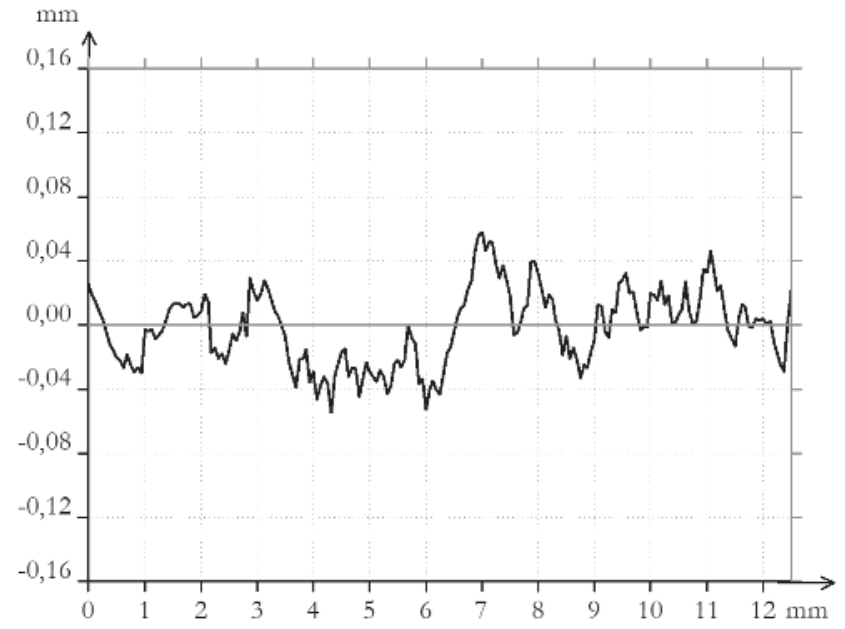

B

Figure 5

Typical measured vertical profiles of clay blocks (a) and concrete blocks - Class 1 (b) 
Table 7

Results of average roughness

\begin{tabular}{|c|c|c|}
\hline $\begin{array}{c}\text { Type of unit } \\
\text { and grout }\end{array}$ & $\begin{array}{c}\text { Average } \\
\text { roughness } \\
\text { Ra (mm) }\end{array}$ & coV (\%) \\
\hline Clay blocks & 0.006 & 5.771 \\
\hline Grout G14 & 0.073 & 9.264 \\
\hline Grout G30 & 0.093 & 13.239 \\
\hline $\begin{array}{c}\text { Concrete blocks-Class 1 } \\
\text { (Co10) }\end{array}$ & 0.143 & 14.341 \\
\hline Grout G14 & 0.138 & 1.051 \\
\hline Grout G30 & 0.173 & 11.324 \\
\hline $\begin{array}{c}\text { Concrete blocks-Class 2 } \\
\text { (Co26) }\end{array}$ & 0.117 & 15.036 \\
\hline Grout G14 & 0.100 & 5.956 \\
\hline Grout G30 & 0.133 & 2.182 \\
\hline
\end{tabular}

values for both types of blocks. Therefore, the type of block material influenced the bond resistance at the block/grout interface. Considering the concrete blocks, the tensile strength also influenced the results. Note that the increase of the "bond" strength (180\% for specimens with grout G14 and $173 \%$ for G30) is consistent with the increase of the tensile strength of the concrete block (181\%). This fact is also qualitatively evident. Figure 4 shows the texture of the grout for each type of block. The grout infill in the concrete block displays a rougher surface than the grout infill in the clay block. The smooth surface of the clay blocks favors the grout slippage and creates a low bond interface between the grout and the webs of the blocks. The roughness is consistent with the nature of the block material surface into which the grout is inserted.

Additional tests were done to quantify texture variation of the internal surfaces of blocks and grouts, in a way similar to Thamboo et al. [16], using an experimental apparatus widely used for metal tribological applications and rock mechanics profile. The roughness average $(\mathrm{Ra})$ is a property to describe irregularities of the surface texture, which is the arithmetic mean of the deviation between the measured vertical and the average profiles. Typical profiles are shown in Figure 5. Table 7 shows the obtained values of Ra, noting that each line contains the obtained results for block and corresponding G14 and G30 grouts. The obtained results show clearly that: a) concrete blocks and corresponding grouts have more irregularities than clay units and their grouts, favoring bond; b) considering each block, the strongest grout presents higher values for $\mathrm{Ra}$, being more capable of penetrating irregularities of the block surface, despite of nearly the same consistency of the weakest grout (see slump results in Table 3 ) and c) considering the two classes of concrete blocks, the irregularities are larger for the weakest blocks; however the influence on the bond strength could not be observed, since failure is typically related to the tensile strength of the webs.

\subsubsection{Failure type of the push-out specimens}

The tested push-out specimens showed a good bond between grout and concrete blocks, enough to prevent grout slippage inside the concrete block's cavity, for all the tested series (see Figure 6). Note that the shells cracked before slippage for concrete units of different classes. On the other hand, the two types of grout slid inside the clay block's cavity. Figure 7 displays a clay block specimen before and after the test.

The failure of the concrete block specimens was characterized by cracks at the concrete blocks webs, the same type described by Soric and Tulin [1] (see Figure 6). This failure was due to the stress transference from the grout infill to the concrete block webs through the common interface. This behavior is justified by the similarity between the materials of the grout and concrete blocks, besides the already mentioned roughness of the contact surfaces. Although no slippage occurred, the failure of the block breaks up the bond, thereby limiting this property.

On the other hand, the grout infill in the clay blocks slipped, as shown in Figure 7. Therefore, the transference of stresses between grout and block web was weak, which meant that there was low adhesion at that interface.

\subsection{Pull-out tests}

As previously mentioned, the pull-out specimens had reinforcement bars. In this work, the anchorage length was calculated
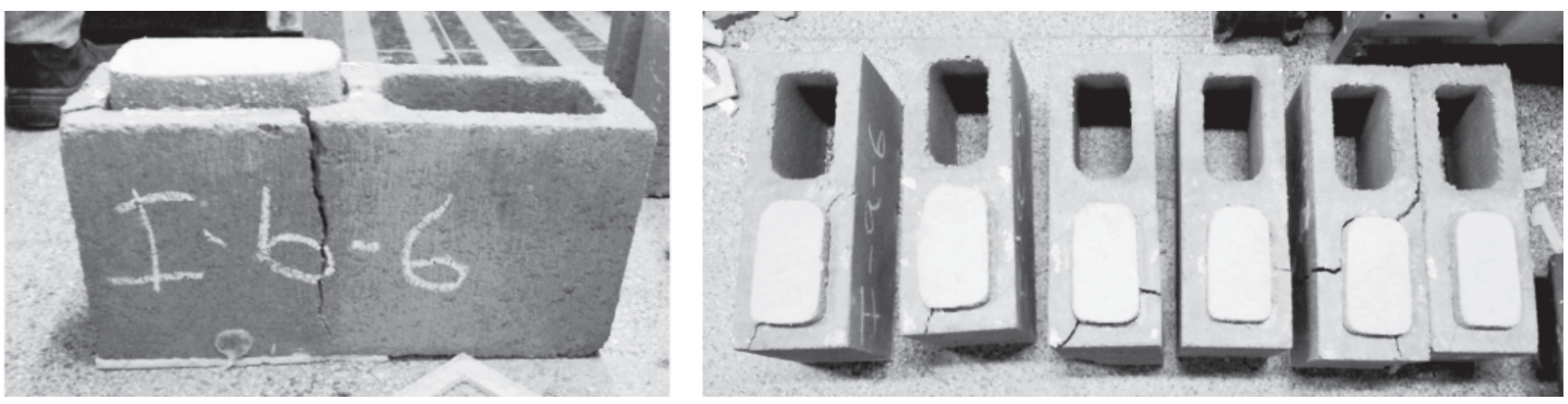

Figure 6

Failure type of push-out specimens of concrete blocks 

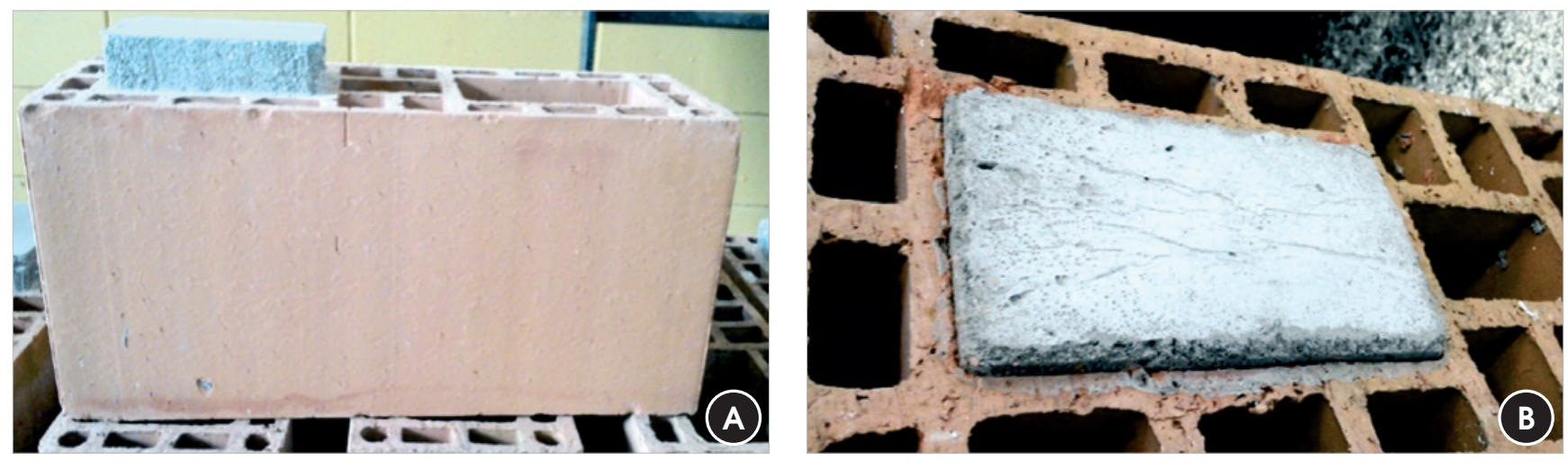

Figure 7

Failure type of push-out clay block specimens before

(a) and after (b) the test

according to the [17] because the assessment of the grout/reinforcement bond stress is more detailed than in the [10]. This code does not consider the influence of the grout strength.

Table 8 shows the anchorage length calculated according to the material properties.

The results obtained show that the calculated anchorage lengths are lower than the actual embedment length adopted for the rebars in the pull-out specimens of this work (see Figure 2). Therefore, the anchorage length was sufficient for the bars of both diameters. The rebars of $12.5 \mathrm{~mm}$ and $16 \mathrm{~mm}$ diameters were chosen because they are the most common in the reinforced masonry in Brazil, in high-rise buildings. The Brazilian Standards for Concrete Block

\section{Table 8}

The calculated anchorage length for concrete and clay blocks

\begin{tabular}{|c|c|c|c|}
\hline Series & Grout & $\begin{array}{c}\text { Diameter } \\
\text { of rebar } \\
\text { (mm) }\end{array}$ & $\begin{array}{c}\text { Anchorage } \\
\text { length (lb) } \\
\text { (mm) }\end{array}$ \\
\hline G14S12 & G14 & 12.5 & 570 \\
\hline G30S12 & G30 & 12.5 & 350 \\
\hline G14S16 & G14 & 16 & 730 \\
\hline G30S16 & G30 & 16 & 440 \\
\hline
\end{tabular}

Structural Masonry [10] and the Clay Block Structural Masonry [11] suggest that the reinforcement housed in the same grouting cavities should not have cross-sectional area higher than $8 \%$ of the corresponding area of the surrounding grout section, considering possible trespass regions. In practical terms, this means using a maximum reinforcement diameter of $20 \mathrm{~mm}$, although it is usual to limit the reinforcement diameter to $16 \mathrm{~mm}$.

\subsubsection{Results of the pull-out of concrete block specimens}

Table 9 shows the mean value of the ultimate load and the maximum stress of the pull-out concrete block specimens for the four series. Figure 8 shows the results of the pull-out loads. Figure 8 also shows the reference values of the yield load and the ultimate load, both in the simple tensile test of the steel rebars, to better understand the results.

The pull-out tests showed that there was a good bond between the reinforcement and the two types of grout. In all cases, the steel bars reached their maximum load without slipping. The load capacity was defined by the reinforcement tension since the steel rebar and the grout did not slip. The results in Table 9 evidence that the diameter limits are practically the same for the bars. The pull-out specimens built with reinforcement of $16 \mathrm{~mm}$ diameter reached an ultimate load higher than the maximum load of the referred bar. The maximum load of the $12.5 \mathrm{~mm}$ diameter pull-out specimens remained close to the maximum load of the corresponding steel

Table 9

Results of the pull-out of concrete block specimens

\begin{tabular}{|c|c|c|c|c|c|c|}
\cline { 2 - 7 } \multicolumn{1}{c|}{} & \multicolumn{2}{c|}{ Concrete blocks - Class I (Co10) } & \multicolumn{3}{c|}{ Concrete blocks - Class 2 (Co26) } \\
\hline Series & $\begin{array}{c}\text { Mean ultimate } \\
\text { load } \\
(\mathbf{k N})\end{array}$ & $\begin{array}{c}\text { Mean ultimate } \\
\text { stress } \\
\text { (MPa) }\end{array}$ & CoV (\%) & $\begin{array}{c}\text { Mean ultimate } \\
\text { load } \\
\text { (kN) }\end{array}$ & $\begin{array}{c}\text { Mean ultimate } \\
\text { stress } \\
\text { (MPa) }\end{array}$ & CoV (\%) \\
\hline CoG14S12 & 96.33 & 784.93 & 1.96 & 89.15 & 726.42 & 0.81 \\
\hline CoG30S12 & 98.17 & 799.98 & 1.79 & 89.24 & 727.17 & 0.53 \\
\hline CoG14S16 & 155.78 & 774.79 & 7.20 & 150.97 & 750.84 & 3.83 \\
\hline CoG30S16 & 159.02 & 790.93 & 4.47 & 148.33 & 737.71 & 0.95 \\
\hline
\end{tabular}




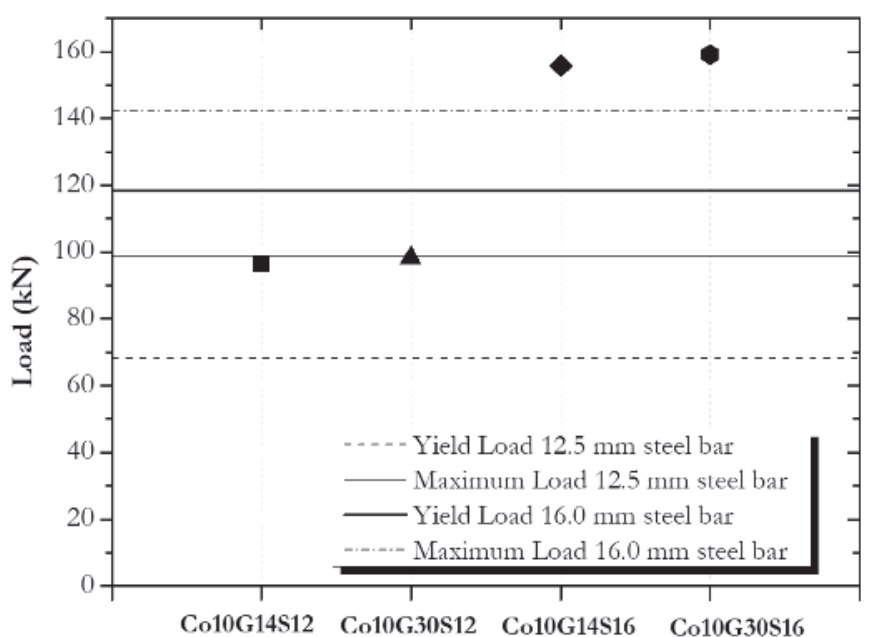

A

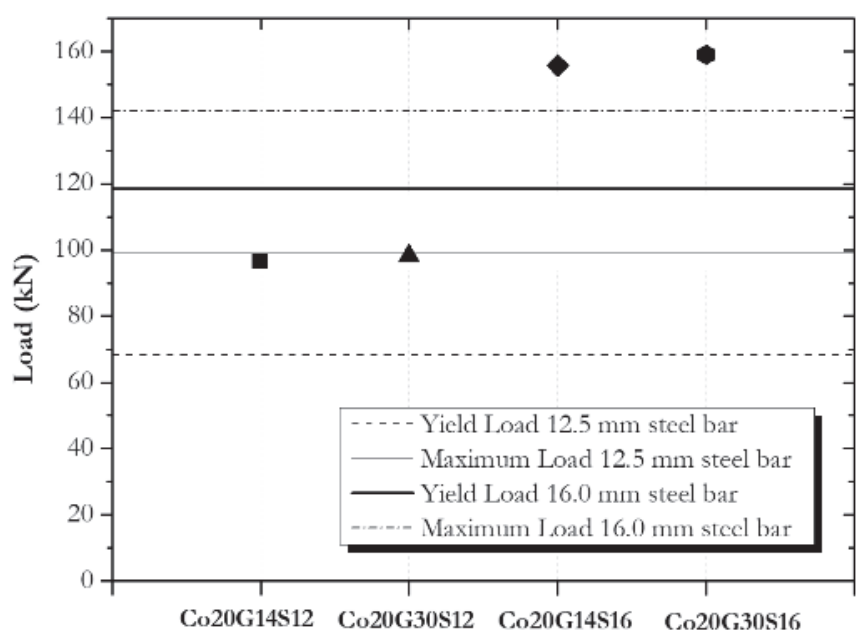

B

\section{Figure 8}

Results of the pull-out of concrete block specimens of the Class 1 (Co10) (a) and Class 2 (Co26) (b) with yield load and maximum load of the reinforcements

bar. The results in Figure 8 clearly show that the specimens' failure was commanded by the type of steel and not by the type of grout. As mentioned earlier, the Brazilian Standards [10] and [11] consider that the maximum tensile load of the reinforcement embedded in the grout cannot be higher than half the yield stress $\left(0.5 \sigma_{\mathrm{y}}\right)$. According to the achieved results, it is apparent that this standardized value is very conservative.

\subsubsection{Results of the pull-out of clay blocks specimens}

Table 10 shows the mean value of the ultimate load and the maximum stress of the pull-out clay block specimens for the four series. Figure 9 presents the results of the pull-out loads. Figure 9 also shows the reference values of the yield load and the ultimate load, both obtained in the simple tensile test of the rebars.

Figure 9 shows that the failure of the clay block specimens was determined by the type of grout. The series Cl10G14S12 and Cl10G14S16 (lower compressive strength and higher water/cement ratio) reached almost the same value of the ultimate load,

\section{Table 10}

Results of the pull-out of clay block specimens

\begin{tabular}{|c|c|c|c|}
\hline Series & $\begin{array}{c}\text { Mean } \\
\text { ultimate } \\
\text { load } \\
\text { (kN) }\end{array}$ & $\begin{array}{c}\text { Mean } \\
\text { ultimate } \\
\text { stress } \\
\text { (MPa) }\end{array}$ & COV (\%) \\
\hline CIG14S12 & 48.47 & 394.95 & 2.36 \\
\hline CIG30S12 & 59.26 & 482.91 & 10.51 \\
\hline CIG14S16 & 48.96 & 243.49 & 3.60 \\
\hline CIG30S16 & 60.11 & 298.94 & 8.50 \\
\hline
\end{tabular}

independently of the reinforcement diameter. The same thing happened with the series Cl10G30S12 and Cl10G30S16 (higher compressive strength and lower water/cement ratio). The specimens filled with grout $\mathrm{G} 30$ were more resistant than with the grout $\mathrm{G} 14$, which is consistent with the roughness measures presented in section 3.2. The push-out results confirm this fact.

Statistical analysis confirms that the failure load of the G30 specimens is significantly different to the specimens filled with grout G14.

The behavior of clay blocks in pull-out tests was not similar to the concrete blocks. The column of grout inside the clay blocks slipped for both types of grouts. Therefore, the reinforcement rebars did

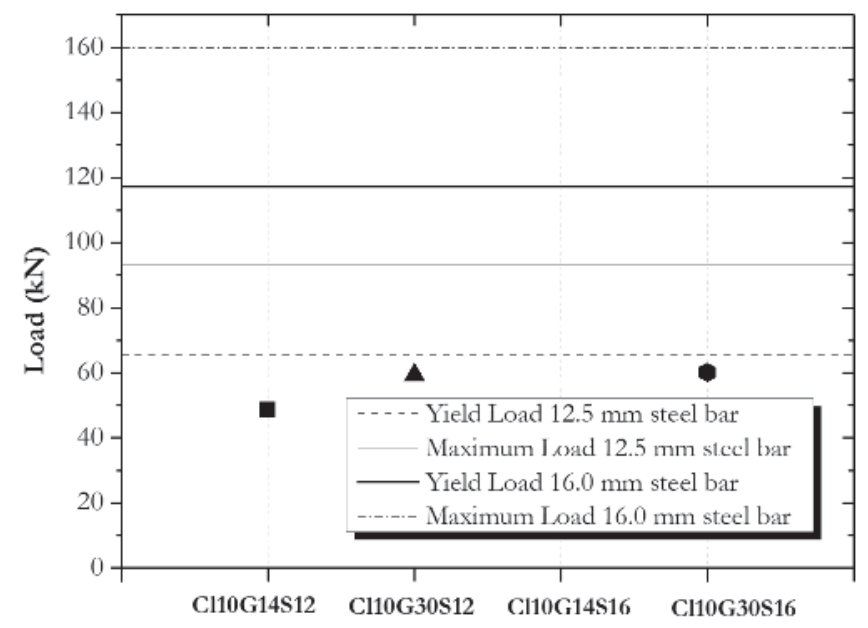

Figure 9

Results of the pull-out of clay block specimens with yield load and maximum load of the reinforcements 

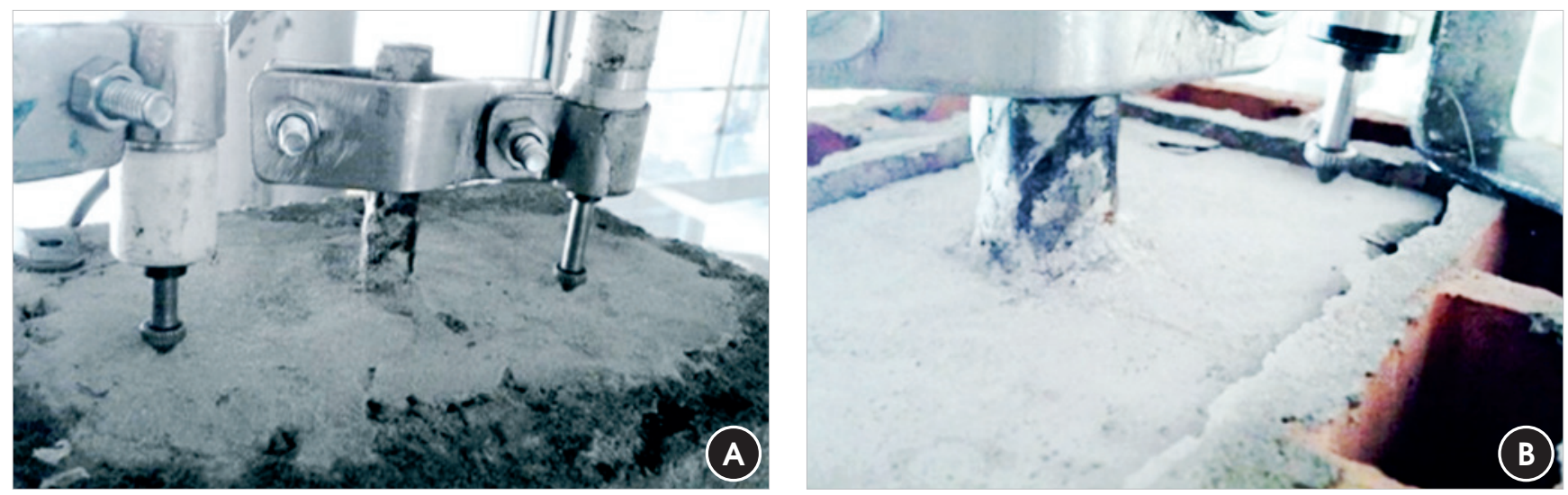

Figure 10

Behavior of grout after the pull-out specimens were tested: concrete block without grout slippage (a) and clay block with grout slippage (b)

not reach their yield stress because the grout slipped before, despite the anchorage length being adequate. The bond strength between the clay block webs and the grout infill was weak.

\subsubsection{Behavior of the block/grout interface}

Another aspect to consider in the tested pull-out specimens regards the behavior of the grout/block interface. When the tensile force was applied to the embedded reinforcement, there was no slippage of the grout inside the cavities of the concrete block. This feature demonstrates that there was sufficient bond strength at that interface, as illustrated in Figure 10a. Although there was slippage of the grout's column inside the clay blocks (see Figure 10b).

\subsubsection{Analysis of the limits of block/grout bond}

The analysis of the block/grout bond limits was carried out only for the clay blocks, since there was no slippage in the concrete blocks. The bond load between the grout and clay block was $11.64 \mathrm{kN}$ for grout G14 and $14.02 \mathrm{kN}$ for grout G30, for a single grouting block.
These loads multiplied by the number of grouting blocks used in the pull-out specimens (4 blocks) set important limits related to the grout/block bond. These values can be compared with the ultimate loads obtained in the pull-out tests, as shown in Table 11.

The results in Table 11 show that the ultimate loads of pull-out tests were approximately equal to the extrapolated limits of the push-out tests. The statistical analysis showed that these limits are not significantly different. Note that these limits should be checked in the reinforced masonry design.

\subsubsection{Different rebar diameters}

The authors of this research speculated on the use of 8, 10 and 20 $\mathrm{mm}$ diameter rebars in the pull-out test, assuming the use of the same materials. Table 12 shows the yield load for three different diameters which have been tested by [18] and [19] under the same test conditions of the rebars in this experimental program $(12.5 \mathrm{~mm}$ and $16 \mathrm{~mm}$ ). Table 12 also shows the ultimate load considering the experimental tests of this study for the concrete blocks and Table 13 for clay blocks.

\section{Table 11}

Load limited by bond and ultimate load of the pull-out tests of clay blocks

\begin{tabular}{|c|c|c|c|c|c|}
\hline \multicolumn{2}{|c|}{ Concrete blocks - Class 1 (Co10) } & & \multicolumn{2}{|c|}{$\begin{array}{l}\text { Pull-out specimens } \\
\text { Ultimate load (kN) }\end{array}$} & \multirow[b]{2}{*}{ ClG30S16 } \\
\hline G14 & G30 & $\mathrm{ClG} 14 \mathrm{~S} 12$ & $\mathrm{ClG} 14 \mathrm{~S} 16$ & CIG3OS12 & \\
\hline 46.56 & 56.12 & 48.49 & 48.96 & 59.26 & 60.10 \\
\hline
\end{tabular}

Table 12

Yield load for different diameters and load limited by spalling achieved in concrete blocks

\begin{tabular}{|c|c|c|c|c|}
\hline \multicolumn{3}{|c|}{ Yield load (kN) } & $\begin{array}{c}\text { Load limited by shell } \\
\text { cracking (kN) }\end{array}$ & $\begin{array}{c}\text { Load limited by shell } \\
\text { cracking (kN) }\end{array}$ \\
\hline$\varnothing 8 \mathrm{~mm}$ & $\varnothing 10 \mathrm{~mm}$ & $\varnothing 20 \mathrm{~mm}$ & $\mathrm{G} 14$ & $\mathrm{G} 30$ \\
\hline 31.01 & 44.94 & 178.19 & 153.60 & 214.60 \\
\hline
\end{tabular}


Table 13

Yield load for different diameters and load limited by bond achieved in clay blocks

\begin{tabular}{|c|c|c|c|c|}
\hline \multicolumn{3}{|c|}{ Yield load (kN) } & $\begin{array}{c}\text { Load limited by bond } \\
(\mathrm{kN})\end{array}$ & $\begin{array}{c}\text { Load limited by bond } \\
(\mathrm{kN})\end{array}$ \\
\hline$\varnothing 8 \mathrm{~mm}$ & $\varnothing 10 \mathrm{~mm}$ & $\varnothing 20 \mathrm{~mm}$ & $G 14$ & $G 30$ \\
\hline 31.01 & 44.94 & 178.19 & 46.56 & 56.08 \\
\hline
\end{tabular}

Table 12 shows that the use of rebar diameters of 8 and $10 \mathrm{~mm}$ in the pull-out specimens of concrete blocks would cause a masonry failure related to the yield load of both steel bars, and not by shell cracking. The $20 \mathrm{~mm}$ rebar diameter is used in the construction of tall buildings, higher than 16 floors. In this case, a block with compressive strength of $16 \mathrm{MPa}$ ( $1 \mathrm{MPa}$ per floor, as a rule of thumb) and a corresponding grout of $32 \mathrm{MPa}$ (twice the block compressive strength related to the gross area) could be indicated. Therefore, with the use of a $20 \mathrm{~mm}$ rebar and the same grout G30, it would have the same effect as using the 8 and $10 \mathrm{~mm}$ diameter rebar. It would be a failure commanded by the yield load of the steel bars (178.19 kN < $214.60 \mathrm{kN}$, see Table 12). If a lower compressive strength grout is used, the failure load would probably be smaller than for the G30 grout, depending on the surface roughness, as shown in section 3.3.1.

Regarding the clay blocks, the masonry failure corresponding to the 8 and $10 \mathrm{~mm}$ reinforcement bars would be commanded by the yield load of rebars. With the use of $20 \mathrm{~mm}$ rebar, the effect would be probably the same as the rebars already shown in this paper $(12.5 \mathrm{~mm}$ and $16 \mathrm{~mm})$, where the masonry limit state would depend on the bond strength of the block/grout interface for the specific grout type.

Table 14 displays a summary of the ultimate stress of the pull-out test of clay blocks referred to the yield stress of the steel bar, for several reinforcement diameters.

As mentioned earlier, the Brazilian Standards [11] considers as a limit half of the yield stress of the reinforcement embedded in the grout $\left(50 \% \sigma_{\mathrm{y}}\right)$. The results in Table 14 show that the limit reduces progressively with the increasing rebar diameter. It is then apparent that the bond stress at the grout/block interface should be considered during the design development to guarantee safety.

\section{Conclusions}

The push-out tests in concrete blocks showed that there is sufficient bond strength between the concrete block and the two types of grout used in this study. This bond prevented grout slippage for both classes of blocks. The push-out tests with clay blocks leaded to grout slippage, denoting a lack of bond.

The higher strength grout with lower water/cement ratio (grout G30) presented higher bond strength compared to the lower strength grout and higher water/cement ratio (grout G14). This fact was evidenced for both concrete and clay blocks.

The pull-out tests with concrete blocks showed that the reinforcements embedded in the grout reached their yield stress without slippage. This feature demonstrated that the anchorage length used in this work was appropriate. The grout did not slip in relation to the concrete block webs. The pull-out with clay blocks showed

\section{Table 14}

Ultimate stress of the pull-out tests of clay blocks referred to the yield stress of the steel rebar for different diameters

\begin{tabular}{|c|c|c|}
\hline \multirow{2}{*}{$\begin{array}{c}\text { Rebar diameters } \\
(\mathbf{m m})\end{array}$} & \multicolumn{2}{|c|}{ Ultimate } \\
\cline { 2 - 3 } & $\mathbf{G 1 4}$ & $\mathbf{G 3 0}$ \\
\hline$\varnothing 8$ & $100 \% \sigma_{\mathrm{y}}$ & $100 \% \sigma_{\mathrm{y}}$ \\
\hline$\varnothing 10$ & $100 \% \sigma_{\mathrm{y}}$ & $100 \% \sigma_{\mathrm{y}}$ \\
\hline$\varnothing 12.5$ & $74 \% \sigma_{\mathrm{y}}$ & $90 \% \sigma_{\mathrm{y}}$ \\
\hline$\varnothing 16$ & $42 \% \sigma_{\mathrm{y}}$ & $51 \% \sigma_{\mathrm{y}}$ \\
\hline$\varnothing 20$ & $27 \% \sigma_{\mathrm{y}}$ & $33 \% \sigma_{\mathrm{y}}$ \\
\hline
\end{tabular}

slippage of the grout's column before the reinforcement rebars achieved their yield stresses. The failure was commanded by the lack of sufficient bond strength of the clay block/grout interface, consistent with the low values of roughness $(\mathrm{Ra})$.

In the case of concrete blocks there should be no restriction limits on the yield stress of reinforcement, in a practical sense and considering other prescribed limits. In contradiction, in the case of clay blocks, additional tests should be carried out for establishing limits, with varying blocks and grouts. The preliminary results indicate limits that should be adopted for a diameter larger than $10 \mathrm{~mm}$, for clay block and grout properties similar to this research. The authors of this paper suggest $75 \%$ for $\varnothing 12.5 \mathrm{~mm}, 50 \%$ for $\varnothing 16 \mathrm{~mm}$ and $25 \%$ for $\varnothing 20 \mathrm{~mm}$ as a reference point for future investigations, while a comprehensive research program covering the bond between different clay blocks and grout infills is not performed.

The two types of bond strength that occur in the reinforced masonry should be considered during design: grout/reinforcement bond and block/grout bond.

\section{Acknowledgements}

The authors would like to thank the Department of Structural Engineering of the School of Engineering of São Carlos at the University of São Paulo for permission to conduct the survey. The authors also would like to thank the Conselho Nacional de Desenvolvimento Científico e Tecnológico-CNPq.

\section{References}

[1] SORIC, Z. and TULIN LG. Bond in reinforced concrete masonry. In: 4th North American Masonry Conference, Los Angeles, California, 1987, p. 47.1-47.16. 
[2] PEREIRA DE OLIVEIRA L.A. Resistência de aderência como parâmetro de compatibilidade entre o graute de enchimentos e as unidades da alvenaria estrutural. In: 5th Internacional Seminar on Structural Masonry for Developing Countries, Florianópolis, Brasil, 1994, p. 214-227.

[3] PEREIRA DE OLIVEIRA L.A. The micro-concrete infill strength's influence on the compressive masonry strength. In: European Ready Mix Organization Congress - ERMCO 98, Lisboa, Portugal, 1998, p.691-700.

[4] BIGGS D.T. Grouting Masonry using Portland Cement-Lime Mortars. In: International Building Lime Symposium, Orlando, Florida, 2005, p.2-15.

[5] SORIC, Z. and TULIN, L.G. Bond Stress/Deformation in Pull-Out Masonry Specimens. Journal. Structure Engineer, v. 115 , n. 10 , 1989; p. 2588-2602. http://dx.doi.org/10.1061/ (ASCE)0733-9445(1989)115:10(2588)

[6] AHMED, K. and FELDMAN L.R. Evaluation of contact and noncontact lap splices in concrete block masonry construction. Canadian Journal of Civil Engineering, v.39, n.5, 2012; p. 515-525. doi: 10.1139//2012-026

[7] CAMLI, U.S. and BINICI, B. Strength of carbon fiber reinforced polymers bonded to concrete and masonry. Construction and Building Materials, v. 21, 2007; p. 1431-1446. doi: 10.1016/j.conbuildmat.2006.07.003

[8] AIELLO, M.A. and SCIOLTI, S.M. Bond analysis of masonry structures strengthened with CFRP sheets. Construction and Building Materials, v. 20, 2006; p. 90-100. doi:10.1016/j.conbuildmat.2005.06.040

[9] Fédération International du Béton (fib). Bond of reinforcement in concrete. Bulletin n. 14, 2002.

[10] ASSOCIAÇÃO BRASILEIRA DE NORMAS TÉCNICAS. Structural Masonry - Concrete Blocks Part 1: Design. - NBR 15961-1, Rio de Janeiro, 2011.

[11] ASSOCIAÇÃO BRASILEIRA DE NORMAS TÉCNICAS. Structural Masonry - Clay Blocks Part 1: Design. - NBR 15812-1, Rio de Janeiro, 2010.

[12] ASSOCIAÇÃO BRASILEIRA DE NORMAS TÉCNICAS. Portland cement and other powdered material - Determination of density. - NBR NM 23, Rio de Janeiro 2001.

[13] ASSOCIAÇÃO BRASILEIRA DE NORMAS TÉCNICAS. Aggregates for concrete - Specification. - NBR 7211, Rio de Janeiro, 2009

[14] WINTER, J.C.F. Using the Student's t-test with extremely small sample sizes. Practical Assessment, Research \& Evaluation, v. 18, n. 10, 2013. http://pareonline.net/getvn. asp?v=18\&n=10.

[15] ASSOCIAÇÃO BRASILEIRA DE NORMAS TÉCNICAS. Steel for the reinforcement of concrete structures - Specification. - NBR 7480, Rio de Janeiro, 2007.

[16] THAMBOO, J.A., DHANASEKAR, M. and YAN, C. Flexural and shear bond characteristics of thin layer polymer cement mortared concrete masonry. Construction and Building Materials, v. 46, 2013; p. 104-113. doi:10.1016/j.conbuildmat.2013.04.002

[17] ASSOCIAÇÃO BRASILEIRA DE NORMAS TÉCNICAS. Design of concrete structures - Procedure. - NBR 6118, Rio de Janeiro, 2007.
[18] KATAOKA, M. N. Beam-column composite connections under cyclic loading: an experimental study. Materials and Structures, v. 48, n. 4, 2011; p. 929-946. doi: 10.1617/s11527-013-0204-4

[19] OLIVEIRA, L.M.F. Numerical and experimental study of the behavior of vertical interfaces of interconnected structural masonry walls, São Paulo, 2014, Tese (doutorado) - Escola de Engenharia de São Carlos, Universidade de São Paulo, 272 p. 